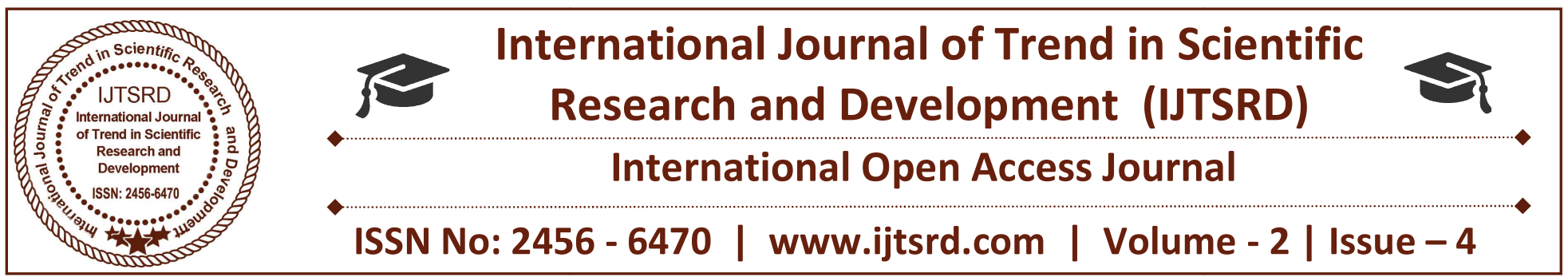

\title{
Practice of Writing Science Fiction in Assamese Language: An Introduction
}

\author{
Samutjal Saikia \\ Junior Research Fellow, Department of Assamese, \\ Dibrugarh University, Assam, India
}

\begin{abstract}
In Assamese literature, science fiction literature had its beginning in a magazine titled 'Abahan' in the year 1937. The story that initiates the tradition of writing science fiction literature in Assamese is 'Bisaratiar Desh' by Hariprasad Barua. Later on, the writing of science fiction drama and science fiction novel were also started. Some of the prominent writers such as Dinesh Chandra Goswami, Bandita Phukon, Abhijit Sharma Baruah, Ranju Hazarika etc. have written various stories, novels related with various aspects of science and thereby enriched the realm of Assamese literature. In the contemporary Assamese literary scenario, science fiction writing is established as a significant literary genre.
\end{abstract}

Keyword: Abahan, Science Fiction, Story, Novel, Literature

\section{INTRODUCTION}

In simple words, science fiction can be defined as a genre in literature that deals with the world of science and technology. In the book $A$ Glossary of Literary Terms edited by M. H. Abrams and Geoffrey Galt Harpham, it is written that the term science fiction can be applied to those narratives in which "... an explicit attempt is made to render plausible the fictional world by reference to known or imagined scientific principles, or to a projected advance in technology, or to a drastic change in the organization of society". In Assamese language, the tradition of writing science fiction has its origin in the twentieth century under the influence of the study of the English science fictions produced in the western society. In the countries of Europe, America, Russia etc. the writers of science fiction had established this genre very strongly and it has comparatively a longer history than the other parts of the world. The Assamese writers of science fiction are influenced to create this genre after their study of the western science fictions.

The writer who is considered as the originator of this genre in Assamese literature is Hariprasad Barua ,who, in the year 1937, published a story in the style of science fiction in the magazine titled 'Abahan'. On the other hand, the tradition of writing science fiction drama emerged in 1956, whereas writing of novel emerged in 1967 and these three are the only literary forms written in the science fiction genre. In this article, I want to give a brief description of the development and nature of science fiction in Assamese language and it is described below:

\section{II. - Science fiction story}

The first Assamese story with which the tradition of writing Assamese science fiction begins is Bisorotiar Desh (Bisorotia's Country), and it was published in the seventh number of the eighth volume of the magazine 'Abahan'. Regarding this story, Sourav Kumar Saliha, on the basis of his research, says "The first Assamese science fiction story is Bisorotiar Desh, written by Hariprasad Barua and published in 1937 in the magazine "Abahan". In this story, there is a character named Faguna who eats hashish from a priest of Sivasagar and in the night, under the hangover of the hashish, dreams a dream in which he talks with a person of the Jupiter via telephone. Due to its relationship with the field of science, this story is characterized as the first Assamese story of science fiction. The next story is published in the year 1938 titled Roxayan (Chemistry) by Nogendra Narayan Chaudhury in the same magazine. Though Assamese 
science fiction writing originated in the beginning of the 20th century, but it flourished in 1980s during which many writers such as Dinesh Chandra Goswami, Santanoo Tamuli, Bandita Phukan, Abhijit Sharma Barua, Ranju Hazarika, Rathindranath Goswami etc. contributed to it. On the other hand, some writers like Sourav kumar Saliha, Bhabendranath Saikia etc. also enriched, in a limited way, the realm of science fiction before 1980s. Some of the prominent stories of Sourav Kumar Saliha are Awaaz (Voice) (1950), Uporot (Above) (1963), Hekh Anurodh (The Last Request) (1993), Moryudyan (Oasis) etc. According to Dines Chandra Goswami, the story that fulfills the characteristics of science fiction is Saliha's famous story Awaaz, written in 1950 and published in the paper 'Asom Batori' in the year 1966. On the other hand, Bhabendranath Saikia's Gahbar (Cave), published in 1968, is another example of science fiction story. This story has its setting in foreign land.

The writer who is very instrumental in popularizing the genre of science fiction in Assamese literature is Dines Chandra Goswami. He has written many stories and novels in the genre and also has translated some of the English stories into Assamese. $\mathrm{He}$ has been contributing to this field from a long time including the period of both the twentieth and twenty first century. As he is related to the field of science in his life, so he realizes the necessity of scientific development in our society and hence, through his articles, translations etc. tries to develop and expand the genre of science fiction. He has written total eight books of science fiction story that includes Bhodrotamapok Jontra (Machine for Weighing Decency) (1985), Portable Smell Absorber (1986), Ak Torongor Dore (Like a Wave) (1995), Abhinna Hriday (Similar Heart) (2004), Kolpojogot (Imaginary World) (2004), Dines Chandra Goswamir Swa Nirbasito Golpo (Dines Chandra Goswami's Self Selected Story), Antorbahi (Coronary) (2011), Notun Xotikar Kolpobastav (Fictitous Reality of the New Century) (2016) etc. Among these notable works, Bhodrotamapok Jontra is the first anthology of science fiction story. Another two prominent literary figures of this genre are Bandita Phukon and Santanoo Tamuli. Bandita Phukon has written many interesting short stories readable for the children, youths and aged persons. Two of her famous works are Xomoi Hoisene( Is It Time) and Ak Rohoishar Hondhanot (In Search of a Mystery). On the other hand, Tamuli's first story is He Sandra Bidai ( Farewell the Moon) written in 1964, and later on, he has written some other stories such as Prasir (Wall), Mayajal (Worldly Illusion), etc. Mayamriga (Illusory Deer) (1998), is his anthology of science fiction story. In the current literary scenario, the future of the science fiction genre seems promising as myriad of writers are contributing to the development of this genre of science fiction by their own writing.

\section{Science fiction Drama}

The first dramatist who has initiated the tradition of writing science fiction drama is Arun Sharma through his play Sthawar (Immovable) published in 1956. Regarding this play, Jugen Chetia gives his opinion as followed: "I believe that Sharma's Sthwar can be claimed as the first science fiction drama in Assamese literature." The play portrays the tremendous development of the science and technology in our society. Moreover, the drama also highlights the threats that may emerge in this world out of this development. The contribution of the famous dramatist Shyamaprasad Sharma is also worth mentioning here who, through his prominent dramas such as Debotar Anyarup (Another Face of God) (1967), Bissakh (Trust) (1992), Mothauri (Embankment) (1992), Momotar Mohakabya, (Mamata's Epic) (1993) Hubha Hutrapat (Auspicious Beginning) (1999) Dumuja (Confusion) (1999), Hekh Asray (The Last Shelter) (1999) etc. enrich the realm of science fiction drama. Dines Chandra Goswami has also written many dramas and some of them are broadcasted through radio such as Paribrajak (Travelleer) (1974), Bigyapan Bigyapan (Advertisement Advertisement), Ak Tarangar Dore (Like a Wave), Alosya (Indolence), Alfa Spondon, Nispriho (Indifference), Acharjya (Astonishment), Uttoron (Promotion), Honghat(Conflict), Hongjug (Connection), Robot Vijay etc. Morever Susil Goswami's Mon Guhaar Andhokarot ( At the Darkness of the Heart's Cave), Amor Jyoti Choudhry's Hanketik (Symbolic) etc. are some of the prominent science fiction plays. But the number of plays written in Assmese are very few and most of them are not published also.

\section{Science Fiction Novel}

The tradition of writing science fiction novel has emerged in the second half of the twentieth century. The first Assamese novel in science fiction was San 2466, Ak April (Year 2466, 1st April) by Dr. Bijoykrisna DevaSharma and it was published in the newspaper titled "Amar Protinidhi" in 1960. In the 
year 1969, after a successful expedition, human being was able to arrive in the moon and it paved the way for other successful expeditions in the sky. Dr. DevaSharma has written his novel Tulokhi Tolot Mrigo Pohu Sore (Deers graze under Black Basil) by taking this time period as backdrop where he shows the miraculous expedition of human beings in the moon. After Devasharma, there are various writers who have written the science fiction novels and some of them are Nabakanta Barua, Dinesh Chandra Goswami, Sakil Jaman,Bandita Phukon, Abhijit Sharma Barua, Ranju Hajarika, Laksminandan Bora, Horekrisna Deka etc. Nabakanta Barua, has written only one novel titled Apodartha. On the other hand, Amulya Barua has written two novels in science fiction that are Akromon (Attack) (1983) and Hondhan ( Investigation)(1992). The novel Akromon has its setting in the possible use of gene in war. In our hostile neighbouring country, a type of huge ant of two inches is created by using gene that can jump up to six feet. This gigantic creature can easily devour a living man in one minute. Our neighbouring country used the soldiers of that ant in order to destroy the animals and human beings of our country. The liquid to control the speed of these waging ants called Kam Rokh could be spread in the plain areas and thus, the ants were prevented from entering our plain region. Consequently, they returned through the route they came and our country was thus rescued. A significant aspect of this novel lies in the field that, along with including scientific information, this novel also includes a political satire. The novel Hondhan (Investigation), gives a story that shows that through information, it can be known that behind the origin of the natural disasters such as earthquake, flood, generally increasing criminal tendency among human beings, plagues among fishes, wrong indication from computers etc. the animals living in the planet Mongolika that are superior to men, are responsible. The novel also shows people's relationship with other planets. Dines Chandra Goswami has also written many science fiction novels. In order to expand and popularize the science fiction in Assamese literature, he has produced many science fiction stories and articles. Moreover, he has translated many stories written outside our country. Some of his novels are Jonakir Jilikani (Glitter of the Moonlight)(1992), Sobdo Nirontor Sobdo(Sound Incessant Sound)(1992), Usmo Prabah (Warm Flow)(1993), Ati Bikhista Homaj (A Special Society) (2004), Atmojibonir Prayakh (Endeavour of Autobiography)(2007), Dibya Upobon (Divine
Garden) (2009), Atmojibonir Ditio Prayakh (Second Endeavour of Autobiography) (2015) etc. The novel Hobdo Niromtor Hobdo portrays the story of the effort of the protagonist Dr. Chandan Choudhury, who is the chief editor of the Regional Publication and Production Centre, to publish book and various challenges that he faces from some people he meets in his life. In the novel Usmo Prabah, the writer gives the story of a young Physics profeesor of 'Anupom Chaudhury College' named Pankaj Phukon. Here the protagonist engages in his works in an electronic lab and the research work of a girl named Sikha Sharma in the Zoology department. The novel continues with the story of their love for each other and the various discoveries done by Pankaj. In the novel Oti Bikhisto Samaj, the writer gives the story of various biotechnological examinations done in the laboratory called Bigyan Mondir. It shows the practice of transferring genes that are used to make the cockroaches active to the tomatoes and thereby making the genetically modified tomato that will make the people active. On the other hand, Santanoo Tamuli has written many science fiction for children. In his novel Prasir (Wall), he shows how through the help of computer imagery simulation and computer aided writing, one can create a story. Some of his other works are Mayajal (Worldly Illusion), Mani Bani aru Akhon Phuloni, Grohjudha (War of the Planets) etc . Electronic Namor Loratu ( The Boy Named Electronic) is his translated science fiction novel. Bandita Phukon has written many novels both for the adults and the children. Among her science fiction novels written for the children are Moulik Golpo, Upanayakh, Anudito Grantha, Jiboni Grantha etc. She has also written some other prominent novels such as Apekhikotabad Teor Babei (Theory of Relativity for Him)(2007), Kio Ane Hoise (Why is It Happening)(2012), Huntihotor Bipod (Problems of Huntihot)(2012), Minur Robot Hokhi (Minu's Robot Friend)(2012), Abeg Aru Juktire ( With Emotion and Logic)(2012), Huntir Robot Kukur,( Hunti's Robot Dog)(2015), Notun Prithibi (New World) etc. In the novel Apekhikotabad Teor Babei, the novel is based on some possible events that may occur in the Theory of Relativity due to the decrease of the velocity of light in a planet named Miranda. On the other hand, in Notun Prithibi, the novelist shows how the selfish and materialist people of the twentieth and twenty first century cut the trees and the mountains and thereby destroying the natural environment, creating the rampant increase of garbage, the destruction of the lives of various animals due to the ultraviolet light 
arisen out of the excessive use of C.F.C. gas and the consequent journey of the people to another planet for a better habitat. Ranju Hajorika has written total fourteen science fiction novels and some of them are Hurja Handhan (Search for the Sun)(1997), Nakhyatra Jayar Gan ,(Song of Winning the Stars)(1999), Prithivir Hotru (Enemy of the World) (2003), Anya Ak Dhoritri ( Another World) (2006) etc. His novels are mainly replete with sky and the animals from other planets. Another novelist of science fiction novel is Abhijit Sharma Barua who has written some popular novels such as Ipar Hipar, Andharat Junak (Moonlight in Darkness), Maya Bandhan (Worldly Attachment) etc.. Besides these abovementioned writers, some other writers such as Lakshmi Nandan Bora, Harekrishna Deka, Devicharan Thakur, etc. also contributed towards enriching this genre. In Lakshmi Nandan Bora's novel titled Kayakolpo published in 2004, he shows the discovery of the medicine called 'Kayakolpo 25' that can defer our youth and prolong our life span and the getting of rebirth by biotechnology. Agontok is the only science fiction novel by the poet, critic and story writer Harekrisna Deka. Debisaran Thakur has also written a very beautiful novel titled Mahaprasthanor Prothot (En Route of a Grand Exit) (2010) that deals with terrorism.

\section{Conclusion}

In Assamese language, though the number of the publication of science based works are many, but the number of science fiction is very few. One of the reasons for this few number of science fiction is that in comparison with other literary genres, very few writers participate in the writing of science fiction. But to make the field of science popular, the writing of science fiction is undoubtedly very essential and the writers of Assamese literature should realize it and try to enrich this significant literary genre.

\section{Reference}

1. Clute, Nicholls and Cohen I. Bernad (ed.), The Encyclopedia of Science Fiction, New York: St Martin's Press, 1995

2. D'ammassa, Don, Encyclopedia of Science Fiction, New York NY 10001132 West

3. Dinesh, Baishya, Asomiya Bijnan Sahitya, first edition, 1982

4. Goswami, Dinesh Chandra, Kitabor Bhichitra Jagat, first edition, 2016

5. Neog, Promod Chandra, Bijnan Sahitya : Asomiya Bijnan Sahityor Bibhinna Dhara, first edition, 1998

6. Sarmah, Shayamaprasad, Bijnan Natak, first edition:2000 